\title{
SYMBOLISM OF LITERARY TITLE IN TRANSLATION
}

\author{
Shama I. M.
}

\author{
One mistranslation in 300 pages of a book is not fatal, \\ but a bad translation of a title can ruin it. \\ Maria Bobadilla-Pérez
}

\section{INTRODUCTION}

About half of a contemporary reader's book list consists of translated literature. But have you ever thought why one of these books imposes you upon its magic, involves you into its plot and you are lost in it up to the last page, while the other book, vice versa, makes you put it aside and not even try to read it more? Can it happen just because a book is simply not 'your' piece of reading, the author is not 'yours' and therefore your inner tuning fork does not resonate with a book? Or maybe it is not a matter of the author at all, as you read a target text, a translated version and it is a translator who is responsible for a book to find its voice in the hearts of readers who belong to different cultures?

History of translation knows a lot of cases when some unsuccessful, careless translations turned brilliant source texts into their mediocre semblance. As a result, many writers, who gained recognition and admiration in their own cultures, the source cultures, appeared to be unappreciated in a recipient culture. Moreover, their popularity in their native countries bewildered the target readers. N. G. Bagdasar'yan ${ }^{1}$, for instance, notes that the foreigners who read the works by Pushkin in translations, are very often surprised about his genius. The situation was analogous to the first translations of the works by N. V. Gogol into English. Up to the XXth century Gogol remained one of the least popular authors in the UK. It was the translation by Constance Garnett published at the beginning of the century that let the English-speaking readership understand: Gogol is a writer of a world-wide significance and, as

Багдасарьян Н.Г. Язык и культура. Культурология / под ред. Н.Г. Багдасарьян. Москва : Высшая школа, 1998. С. 115. 
K. I. Chukovsky ${ }^{2}$ stated, the «losses» of the readers of the earlier translations are «innumerable».

Certainly, you can't but agree with D. M. Urnov that it's wrong to blame only and mainly the lack of translations or their poor quality for «the snags on a writer's road to the readers from a different country» ${ }^{3}$. But it's not also right to diminish the significance of a good communicative translation for a source text to take in the target culture such a place that is no less respectable than it occupies in its own culture and literature. After all, E. Hemingway truly appreciated «War and Peace» by L. Tolstoy only after he had read it in the translation by C. Garnett ${ }^{4}$. Before that he couldn't even finish reading it up to its end. Analogously, when N. Ya. Gal' analysed the situation that preceded the establishing of the translation school by I. A. Kashkin, she stressed that it's not possible to appreciate the creative works by Balzac or Dickens if you read the translations done in the 30-ies of the XXth century ${ }^{5}$.

It's not for nothing that literary translation is called one of the most difficult types of translation. This difficulty comes from its «twofold» ${ }^{6}$ status and is directly connected with the very nature of a literary source text, the communicative function of which is to produce an emotional and aesthetic impact on its reader. Hence, the task of literary translation is to re-create this kind of impact in a target text ${ }^{7}$. If the task is successfully fulfilled, «the target literary text, on the one hand, substitutes the original among the target readers, but on the other hand, it becomes the fact of literature in the target culture» ${ }^{8}$.

However, this status could be reached not without some hardships. Literary translation is always a challenge. It's fair to state that «literature is a particularly intense and heightened form of discourse which exploits to the hilt all the potentialities of language both structurally (sound,

${ }^{2}$ Чуковский К.И. Высокое искусство. Москва : Сов. писатель, 1988. С. 129.

3 Урнов Д.М. «Живое описание» (Гоголь и Диккенс). Гоголь и мировая литература / отв. ред. Ю.В. Манн. Москва : Наука, 1988. С. 22.

${ }^{4}$ Hemingway E. A Moveable Feast. London: Jonathan Cape, 1964. P.119.

${ }^{5}$ Галь Н.Я. Слово живое и мёртвое: Из опыта переводчика и редактора. Москва : Время, 2007. С. 226.

6 Казакова Т.А. Художественный перевод: в поисках истины. Санкт-Петербург : СПбГУ, 2006. С. 4.

${ }^{7}$ Комиссаров В.Н. Теория перевода (лингвистические аспекты). Москва : Высш. шк., 1990. C. 95 ; Delabastita D. Literary translation. Handbook of translation studies / ed. by Y. Gambier \& L. van Doorslaer. Vol. 2. Amsterdam / Philadelphia : John Benjamins Publishing Company, 2011. P. 69.

${ }^{8}$ Казакова Т.А. Художественный перевод: в поисках истины. С. 3. 
vocabulary, grammar ...) and in terms of stylistic and sociolinguistic differentiation $»{ }^{9}$. For this very reason one of the most important traits of adequate translation is its ability «to re-create correctly the content-andstylistic system of the source text» and «to perform in the native culture and literature of a translator the function, that is similar to the function it performs in its own culture and literature» ${ }^{10}$. The creation of the target text of such high quality is quite difficult and laborious. Above all, it's a co-creativity of a translator and a writer. In this co-creation the language competence of a translator is actualized, as well as his / her cultural competence. The latter one is not unimportant, because no translation is possible without the cultural awareness. But there are a lot of artefacts, that do not coincide in two cultures (the source and the target ones) and it obviously triggers a number of problems in the process of translation. These problems are usually connected with the so-called «asymmetry between national cultures») ${ }^{11}$.

In a literary text (both in the original and in its translation) these incongruous, 'asymmetric' phenomena are presented by cultural words, phraseologisms, proper names, etc. But here in the article the focus of the analysis will be put on the phenomenon that traces back to the dawn of human culture, permeates its every level and is a kind of a core for every literary text, allowing thus to judge objectively about the source text author's intent and to form the interpretative goals of a translator. This phenomenon in focus is symbol. Cultural symbols today evoke a great interest among the researchers in various fields, because the scientists search for «the correlation between a conceptual sphere of culture and a conceptual sphere of language»» ${ }^{12}$. Symbols act as a specific system, as a peculiar language of any culture. Symbols are like a matrix where the human beings fix their knowledge of the world as well as the knowledge

${ }^{9}$ Delabastita D. Literary studies and translation studies. Handbook of translation studies / ed. by Y. Gambier \& L. van Doorslaer. Vol. 1. Amsterdam / Philadelphia : John Benjamins Publishing Company, 2010. P. 199.

10 Новикова М.А. Эквивалентность и адекватность переводов: жанровый аспект. Коммуникативная направленность текста и его перевод. Киев, 1988. С. 4.

11 Есакова М.Н. Межкультурная асимметрия как переводческая проблема. Вестник МГУ. Серия 19. Лингвистика и межкультурная коммуникация. 2000. № 2. C. 91-99.

12 Белова А.Д. Универсальное и идиоэтническое в языках на фоне мировых тенденций глобализации и унификации. Науковий вісник кафедри ЮНЕСКО Киїського державного лінгвістичного університету (ЛІНГВАПАКС- VIII). Серія «Філологія. Педагогіка. Психологія». 2000. Вип. 3А. С. 61. 
of their own place in this world. Symbols form some kind of a 'universal language of culture' and this language inevitably penetrates into any text born by this culture.

The attention in the article will be concentrated on a literary text translated into another language. More specifically, the article aims to expose a literary title as a part of the symbolic language of a literary text. The assumption is made that the adequacy of the target text greatly depends on the ability of a translator to comprehend all the nuances of meaning of a title, especially those nuances which are connected with the interpretation and decoding of symbols of the source culture. It is also assumed that maximum proximity of a target text to its original can be attained only if cultural symbolism of a source text is reproduced in translation to the utmost.

The assumption is exemplified by the titles from «The Tommyknockers» by Stephen King in comparison with its Russian translations published in 1997 and 2013.

\section{Title as a significant element of a literary text}

The researchers have a long-standing interest in literary titles. Ye. A. Tutatina ${ }^{13}$ states that as far back as the beginning of the 20th century G. E. Lessing showed his interest in titles. J. Levý ${ }^{14}$ notes that Lessing's remarks are cogent enough even today. The XXth century was marked with the emerging of a new science, titrology, and «has multiplied the subtleties of the title apparatus» ${ }^{15}$.

In the scientific papers a title is viewed as an element of the paratext ${ }^{16}$ or metatext ${ }^{17}$, as a part of the text environment ${ }^{18}$, as a marker of the

13 Тутатина Е.А. Заглавие книги: прагматика, поэтика и эволюция. Неофилология. 2019. № 5(19). С. 250.

${ }^{14}$ Levý J. The Art of Translation / Translated by P. J. Corness. Ed. by Z. Jettmarová. Amsterdam / Philadelphia : John Benjamins Publishing Company, 2011. P. 22.

15 Genette G., Crampé B. Structure and Functions of the Title in Literature. Critical Inquiry. 1988. Vol. 14. № 4. P. 695.

${ }^{16}$ Ibid. Pp. 692-720.

${ }^{17}$ Lotman Yu.M. The Semiotics of Culture and the Concept of a Text. Journal of Russian and East European Psychology. 1988. Vol. 26. Issue 3. P. 52-58.

18 Nord Ch. Text Analysis in Translation Theory, Methodology, and Didactic Application of a Model for Translation-Oriented Text Analysis. Translated from the German by Ch. Nord \& P. Sparrow. Amsterdam, New York : Rodopi, 2005. P. 43. 
intertext $^{19}$. When C. Iliescu Gheorghiu gives a definition of a title, she stresses that «a very simplistic definition of the term would say a title is the name of a text» ${ }^{20}$. An analogous approach is used by Z. Ya. Turayeva, though she adds that a title is the name of a text only linguistically. If to define a title semiotically, it's «the first sign of a text» ${ }^{21}$. In V. A. Lukin's monograph a title is described as «an integral and relatively autonomous sign» that «represents a text according to pars pro toto principle» ${ }^{22}$. But it should be noted that, being a sign, a title comprises various signs within itself and thus can be termed «the collection point or the melting pot of different types of raw materials» ${ }^{23}$.

The scholars often emphasise the indispensable link between a title and its text. I. R. Gal'perin, for instance, underlines that «a title is a compressed, unrevealed content of a text $\rangle^{24}$. The full meaning of a title can be comprehended only after all relations between a title and its text have been grasped $^{25}$.

$\mathrm{Yu}$. M. Lotman's ideas about the relations of a text and its title are widely accepted in modern title science. The Tartu semiotician stated that a title and its text, on the one hand, «may be regarded as two independent texts», but on the other hand, «they may be regarded as two subtexts of a single text» ${ }^{26}$. Yu. M. Lotman came to a conclusion that in the process of interaction a title and a text arise «complex semantic flows generating a new message ${ }^{27}$.

19 Чернявская В.Е. Лингвистика текста: поликодовость, интертекстуальность, интердискурсивность. Москва : ЛИБРОКОМ, 2009. С. 248.

${ }^{20}$ Iliescu-Gheorghiu C. What's in a title? A cognitive approach to the role played by translated text labels and (un)adapted semiotic elements. Revista Alicantina de Estudios Ingleses. 2001. № 14. P. 94. DOI: https://doi.org/10.14198/raei.2001.14.06.

21 Тураева 3.Я. Лингвистика текста (Текст: структура и семантика). Москва : Просвещение, 1986. С. 53.

22 Лукин В.А. Художественный текст: Основы лингвистической теории и элементы анализа. Москва : Ось-89, 1999. С. 61.

${ }^{23}$ Taha I. Semiotics of Literary Titling: Three Categories of Reference. Applied Semiotics / Sémiotique Appliquée (AS/SA), 2009. Vol. 9. № 22. P. 43.

24 Гальперин И.Р. Текст как объект лингвистического исследования. Москва : КомКнига, 2007. С. 133.

25 Домашнев А.И., Шишкина И.П., Гончарова Е.А. Интерпретация художественного текста. Москва : Просвещение, 1988. С. 434 ; Кухаренко В.А. Интерпретация текста. Москва : Просвещение, 1988. С. 924 ; Nsiah J., Marfo Ch. What's In a Title? A Reading of Amma Darko's The Housemaid. Matatu. Journal for African Culture and Society. 2011. Vol. 39. № 1. P. 363.

${ }^{26}$ Lotman Yu.M. The Semiotics of Culture and the Concept of a Text. P. 57-58.

${ }^{27}$ Ibid. P. 58. 
The complexity of the afore-mentioned relations manifests itself in the title functions. G. Genette and B. Crampé distinguish three basic ones: designation, indication of the context and seduction of the public ${ }^{28}$. Apart from it, a number of other functions are differentiated. They are informative and phatic functions ${ }^{29}$, nominative and predicative functions $^{30}$, onomasiological, delimitative, prognostic functions, the function of the actualisation of a text concept ${ }^{31}$.

The symbolic function of a literary title is also often spoken of and the symbolic type of a literary title is identified ${ }^{32}$. «The symbolic relations between a title and a 'global context'» are described by G. Genette and B. Crampé ${ }^{33}$. This aptitude of a title for gaining a symbolic meaning is of a particular interest, because further the article will discuss how symbols of culture become titles or are included into a title as its part and, consequently, help comprehend deeper meaning of a text, discern those relations of textual elements that are less / not evident in the process of cursory reading of a text.

\section{Symbol and a literary title}

Literary titles will be explored here through text symbolism. Symbol is understood according to S. S. Averintsev, who defined it as «an image taken in the aspect of its signification and a sign endowed with all the seamlessness of a myth and with inexhaustible polysemy of an image» ${ }^{34}$. Premised on this explanation of symbol's nature, S. S. Averintsev suggests distinguishing two levels of text analysis: «the description of a

${ }^{28}$ Genette G., Crampé B. Structure and Functions of the Title in Literature. P. 708.

${ }^{29}$ Viezzi M. Titles and translation. Haasteena, Perspektivet som utmaning, Point of View as Challenge, Perpektivitat als Herausforderung. VAKKI-symposium XXXIII 7.-8.2.2013. Ed. by M. Eronen, M. Rodi-Risberg. Vaasa: VAKKI Publications, 2013. Vol. 2. P. 375. URL: http://www.vakki.net/publications/ 2013/VAKKI2013_Viezzi.pdf.

${ }^{30}$ Гальперин И.Р. Текст как объект лингвистического исследования. С. 133.

${ }^{31}$ Кухаренко В.А. Интерпретация текста. С. 91.

${ }^{32}$ Гальперин И.Р. Текст как объект лингвистического исследования. С. 134 ; Levý J. The Art of Translation. P. 122; Lodge D. The Art of Fiction. London: Vintage Books, 2011. P. 194 ; Martashvili N. E. Nature of correlation of the title and literary text (on the basis of French literature). European science review. 2018. № 3-4. P. 302. URL: https://cyberleninka.ru/article/n/nature-of-correlation-of-thetitle-and-literary-text-on-the-basis-of-french-literature.

${ }^{33}$ Genette G., Crampé B. Structure and Functions of the Title in Literature. P. 708.

${ }^{34}$ Аверинцев С.С. Символ художественный. София - Логос. Словарь. Киев : Дух і Літера, 2001. С. 156. 
text and interpretation of different layers of its symbolism» ${ }^{35}$. In view of this idea, symbolism will be further treated as a peculiar language of culture which is inevitably reflected in a literary text. It means that symbolism requires separate approach when being translated or, to be more precise, when being re-created in a different culture.

J. C. Cooper underlines that symbolism «is an instrument of knowledge and the most ancient and fundamental method of expression, one which reveals aspects of reality which escape other modes of expression $»{ }^{36}$. For both a translator and a literary text interpreter it means that symbolism may allow discerning sense that seems to be invisible at first sight, i. e. comprehending that very genuine intention that the author of the source text puts into the original. Symbolism helps understand the message that is not expressed openly or explicitly and, as a result, among the multitude of senses it becomes possible to single out that one which is principal for this very text.

Symbol is characterized by the integral unity of associativity, emotivity, cultural determinacy and stability, polysemy, contextual determinacy. Taking these traits into consideration, an attempt to read the source text through the symbols that it contains makes it possible to grasp deeper any context at any level of linguostylistic analysis. Thus, for example, deciphering symbols of a literary text may brighten the system of characters of the source text, reveal the peculiarities of its chronotope, plot, architectonics, etc.

The aforementioned is in compliance with Yu. M. Lotman's words, who said that symbol is «a special kind of 'textual gene'»" ${ }^{37}$. Yet if symbol is really «a gene», it means that it can construe a literary text at some deep, primal levels and it can't but be reflected in the system of text titles. When a literary text is interpreted symbolically, all the hallmarks of a title become more distinct and the significance of a title increases manifold, because a title turns into a kind of a key to deciphering symbols of this very text. A title thus fulfils all its basic functions, but at a deeper symbolic level.

${ }^{35}$ Ibid. C. 157.

${ }^{36}$ Cooper J.C. An Illustrated Encyplopaedia of Traditional Symbols. London : Thames \& Hudson, 1987. P. 7.

${ }^{37}$ Lotman Yu.M. The symbol as plot-gene. Lotman Yu. M. Universe of the mind: A Semiotic Theory of Culture. Translated by A. Shukman. Bloomington and Indianapolis : Indiana University Press, 1990. P. 101. 


\section{Re-creating literary title symbolism in translation}

When you are going to translate a title, it may seem to be not a serious task at all, because there are so many recommendations given by well-experienced translators, so many scientific investigations in which the best title translations are described, the translation procedures are explored and theoretical conclusions are given. For example, B. Scharper observes Stieg Larsson's «Millenium trilogy» and raises «issues about the validity of the translation of titles on the one hand and the validity of the notion of the literary title on the other hand ${ }^{38}$. C. Iliescu Gheorghiu $^{39}$ stresses the importance of titles in intercultural communication and studies translated titles within a cognitivecommunicative framework.

M. S. Doyle ${ }^{40}$ assesses the quality of translation titles created in English when contemporary Spanish and Spanish American fiction is transferred. G. Sapiro ${ }^{41}$ examines the literary titles translated from French into English and concludes on the circulation of French literature in the USA. M. Farghal and H. Bazzi ${ }^{42}$ compare English fiction titles rendered into Arabic. Ch. Nord examines a corpus of titles in four languages (English, German, French and Spanish) and believes that translators should be aware of the nuances of the forms and functions of book titles in order «to provide a sound foundation for their translation» ${ }^{43}$.

These are only several examples of how literary titles are investigated in terms of their translation in other languages. But, surely, the number of such research studies is numerous in all the countries, including

38 Schaper B. The Importance of The Literary Title and Its Implications for Translation Theory. Focus on German Studies. 2013. Vol. 20. Cincinatti: McMicken College of Arts \& Sciences. P. 102.

${ }^{39}$ Iliescu-Gheorghiu C. What's in a title? A cognitive approach to the role played by translated text labels and (un)adapted semiotic elements.

${ }^{40}$ Doyle M.S. Contemporary Spanish and Spanish American Fiction in English: Tropes of Fidelity in the Creation of Translation Titles. Translation Review. 1989. Vol. 30-31. Pp. 41-46. URL: https://doi.org/10.1080/07374836.1989.10523464

${ }^{41}$ Sapiro G. Translation and Symbolic Capital in the Era of Globalization: French Literature in the United States. Cultural Sociology. 2015. Vol. 9. Issue 3. Pp. 320-346.

42 Farghal M., Bazzi H. Translation of English fiction titles into Arabic. Translation and Interpreting. 2017. Vol. 9. N. 2. Pp. 114-137.

${ }^{43}$ Nord Ch. Paving the way to the text: forms and functions of book titles in translation. Russian Journal of Linguistics. 2019. Vol. 23. N. 2. P. 328. URL: https://cyberleninka.ru/article/n/paving-the-way-to-the-text-forms-and-functions-ofbook-titles-in-translation 
Ukraine, where there are a lot of works on titrology. For instance, a search request with a keyword «title» was made on 09 January 2021 and the official site of the V. I. Vernadsky National Library of Ukraine suggested about 15400 articles and thesis where titles are investigated.

Regarding such great number of different works devoted to translating literary titles, it would seem that you could follow the advice and create an adequate target title of any source text. But actually it appears to be not as easy as it seems to be. Otherwise G. Genette and B. Crampé wouldn't have to pay attention to «the very common habit of modifying the title during a translation of a work» ${ }^{44}$. Translators' miscues in reproducing literary titles often become a point of discussion. J. Levý wrote about the poetics of translation and devoted a large part of the chapter to the issue of translating book titles. He regretted that «the translator succumbs to all linguistic pitfalls, be it real ambiguity or false

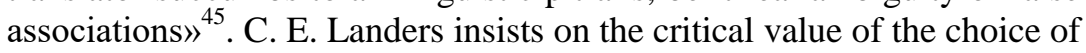
title for a target text. Very expressively, though justified, he exclaims: "while a textual inaccuracy may be over-looked, an error in the title will be there every time the book is referred to ${ }^{46}$. M. Bobadilla-Pérez tries to answer the question «what lies behind the translation of a title?» and comes to the conclusion that «the process of translation of the title is not so different from the process of translating other linguistic utterances, but the basic dissimilarity falls in the 'search' of the title's meaning» ${ }^{47}$.

What is said inevitably reminds of the aforementioned idea that a title can be more or less completely understood only after the text itself has been read up to the end, i. e. retrospectively. It is this very retrospective comprehension of meaning of a title that makes it necessary and important to interpret the original in a thorough, deep and objective way. G. Genette and B. Crampé, while contemplating about a thematic title, stressed the significance of «a particular semantic analysis, in which the role played by interpretation of the text is not insignificant» ${ }^{48}$. R. Stolze also emphasised the dependence of translation «on one's text

${ }^{44}$ Genette G., Crampé B. Structure and Functions of the Title in Literature. P. 708.

${ }^{45}$ Levý J. The Art of Translation. P. 125.

${ }^{46}$ Landers C.E. Literary Translation: A Practical Guide. Clevedon, Buffalo, Toronto, Sydney: Multilingual Matters, 2001. P. 142.

47 Bobadilla-Peréz M. Relevance and Complexities of Translating Titles of Literary and Filmic Works. Huarte de San Juan. Filologia y Didactica de la Lengua. 2007. N. 9. Pp. 119.

${ }^{48}$ Genette G., Crampé B. Structure and Functions of the Title in Literature. P. 708. 
interpretation and language proficiency» ${ }^{49}$. Z. Ya. Turayeva outlines that «the correct understanding of a title $\langle\ldots\rangle$ is closely connected with the functioning of integrative relations and with a text taken as an integrating phenomenon» 50 .

However, not only the meaning of a title depends on general understanding of a text. A title itself produces a back influence on a text and «provides a certain direction of interpretation and constitutes a focus or concentration of textual data» ${ }^{51}$. The same kind of relations of a title and a text is accentuated by other scientists too ${ }^{52}$.

Taking into account the complicated interaction between a text and its title, as well as keeping in mind all other peculiarities of a title that have been mentioned before, it becomes obvious that translation of such element of a text may turn to be not as easy. Hence, the role of a translator in this process is undeniably important, «even more prominent than in the case of other types of the text» ${ }^{53}$. The importance and prominency of a translator's role are facilitated not only by the high level of competence in both the source and the target languages, but also by profound knowledge of peculiarities of cultures (of the source and the target ones, but very often of some other cultures as well). The reason is quite clear: "when a person is given the task of translating a text from one language into another one, the goal of this task is to facilitate communication between people of different cultures $\gg$.

49 Stolze R. Hermeneutics and translation. Handbook of translation studies / Ed. by Y. Gambier \& L. van Doorslaer. Vol. 1. Amsterdam / Philadelphia : John Benjamins Publishing Company, 2010. P. 146.

${ }^{50}$ Тураева 3.Я. Лингвистика текста: (Текст: структура и семантика). С. 55.

51 Nsiah J., Marfo Ch. What's In a Title? A Reading of Amma Darko's The Housemaid. Pp. 365-366.

52 Кухаренко В.А. Интерпретация текста. С. 92-93 ; Чернявская В.Е. Лингвистика текста: Поликодовость, интертекстуальность, интердискурсивность. С. 200; Bobadilla-Peréz M. Relevance and Complexities of Translating Titles of Literary and Filmic Works. P. 117; Lemarié J., Lorch Jr. R. F., Péry-Woodley M.-P. Understanding How Headings Influence Text Processing. Discours. Revue de linguistique, psycholinguistique et informatique. A journal of linguistics, psycholinguistics and computational linguistics. 2012. № 10. P. 376. URL: http://journals.openedition.org/discours/8600; DOI: https://doi.org/10.4000/ discours.8600; Viezzi M. Titles and translation.

53 Awedyk S. On translating titles of literary works. Folia Scandinavica Posnaniensia. 1992. Vol. 1. P. 61. URL: https://pressto.amu.edu.pl/index.php/ fsp/article/view/11120/10677.

${ }^{54}$ Stolze R. Hermeneutics and translation. Handbook of translation studies. P. 141. 
This approach is definitely realised when the genuine sense of a literary original and its title is revealed by means of the interpretation based on deciphering symbols of culture that function in a source text.

When literary text symbolism is to be analysed in the original, in its translation perspective or in the perspective of translation quality assessment, an interpretation algorithm includes several major steps.

In the source text interpretation perspective:

1) symbols are identified in the source text. For that the combination of several methods is consecutively applied, namely: the method of analysis of definitions, the thesaurus method, the descriptiveethnographic method, the functional method; 2) the source text symbols are classified on the basis of subject, distributive, functional and other criteria; 3 ) the source text symbols are interpreted by the use of the combination of such methods as historical-genetic, structuraltypological, contextual and comparative.

In translation perspective one more step is added:

4) the source text symbols are reproduced in the target text and the correspondences used by a translator should fully reflect the information, that has been got at the previous levels of analysis.

In the target text assessment or translation criticism perspective the algorithm is enlarged by one more step:

$5)$ the source text symbols are compared with their correspondences from the target text on the basis of the previous data and conclusions are made after symbolism of the source text has been interpreted and compared with the symbolism of the target text.

This algorithm was first introduced in the thesis by I. N. Shama ${ }^{55}$, later it was exemplified and detailed ${ }^{56}$.

55 Шама И.Н. Функционирование символа в художественном тексте: сопоставительный и переводоведческий аспекты (на материале астральной символики «Вечеров на хуторе близ Диканьки» Н.В. Гоголя) : дис. ... канд. филол. наук : 10.02.19. Одесса, 1993. 278 с.

56 Новикова М.А., Шама И.Н. Символика в художественном тексте. Символика пространства (на материале «Вечеров на хуторе близ Диканьки» Н.В. Гоголя и их английских переводов) : учебное пособие. Запорожье : Акцент Инвест-трейд, 2013. 212 с. ; Шама И.Н. Перевод - искусство понимать... Запорожье : Просвіта, 2005. 240 с. 


\section{4. "The Tommyknockers" by Stephen King: title symbolism in translation}

\subsection{The novel in study}

Stephen King is a writer to whom the attitude lacks unanimity. On the one hand - a lot of appreciation, absolute delight and acceptance, felt in the statements like «Stephen King is one of the most famous and well read authors of all times» ${ }^{57}$, «an author who indisputably belongs to a pantheon of several of the best writers in the genre of horror fiction» ${ }^{58}$. On the other hand - fierce disapproval from the representatives of literary criticism. Harold Bloom, for example, is quite ferocious saying: «I find King very hard to read». And then he continues: «the triumph of the genial King is a large emblem of the failures of American education» ${ }^{59}$.

These two views on S. King seem to be poles apart and all the same they prove the obvious and undeniable fact: Stephen King is a phenomenon in contemporary American (and world) literature. He is often called 'the horror master', though his body of fiction is not limited to horror fiction only. As H. Strengell remarks, «he has chosen the horror formula and enriches it with other literary genres ${ }^{60}$. S. King represents mass culture in literature. Among his works there is «a lot of mainstream (i.e. non-genre) fiction» ${ }^{61}$. There exists even the so-called 'King-dom' that includes the total oeuvre by S. King and the entire industry that rose around him (comic books, movies, games, etc.). All this became possible due to «the obvious marketability associated with King's name» ${ }^{62}$.

Today S. King is super-popular. He is studied at schools and universities; scientific papers are written on him; his books are filmed ${ }^{63}$. But despite this, the scope of researchers' interest refers mainly to a

57 Wood R. Stephen King : a literary companion. Jefferson, North Carolina, London : McFarland \& Company, Inc., 2011. P. 1.

58 Buday M. Demystification of Stephen King's Fiction in the Context of Postmodernism. Prešov: Vydavatel'stvo Prešovskej univerzity, 2015. P. 8. URL: https://www.researchgate.net/publication/292149764

59 Bloom H. Introduction. Stephen King (Bloom's Modern Critical Views) / Ed.

by H. Bloom. New York: An imprint of Infobase Publishing, 2007. P. 2.

${ }^{60}$ Strengell H. Dissecting Stephen King: from the Gothic to Literary Naturalism. The University of Wisconsin Press, Popular Press, 2005. P. 3.

${ }^{61}$ Wood R. Stephen King : a literary companion. P. 3.

${ }^{62}$ Magistrale T. Hollywood's Stephen King. Palgrave Macmillan, 2003. P. xi.

${ }^{63}$ Wood R. Stephen King : a literary companion. P. 19. 
certain, limited set of books (the fact that has been noticed by M. A. Perry and P. McAleer ${ }^{64}$ ). Quite a number of texts are left outside the frames of academic concern. One of such texts is «The Tommyknockers», published in 1987.

The novel was out of luck from the very beginning. Being interviewed by «The Rolling Stones» ${ }^{65}$, King himself admitted the book to be «awful». R. Wood characterises «The Tommyknockers» as «not one of King's best novels» ${ }^{66}$. M. G. Baugham states that the story about the tommyknockers is «one of the commercial and critical failures» 67 .

Miniseries, released in 1993, also appeared to be «a poor adaptation and difficult to watch ${ }^{68}$. S. King, being asked about that series, said that he «didn't care very much for «The Tommyknockers» because it just didn't seem that people doing it got behind the project sufficiently and felt the story» ${ }^{69}$.

Then why has the novel been chosen for the analysis here? There are several reasons for this choice. To begin with, as is known, tempora mutantur. In course of time (now more than thirty years passed since the novel was first published) the views of critics, readers and even the author himself may change. Thus, no matter how much dissatisfied with the novel he was, later, in 2014, S. King confessed that «there's a really good book in here» ${ }^{70}$. The literary establishment is also reconsidering their perception of the book $^{71}$ and here is the result of such revision of approaches: «Universal Pictures» is going to bring «The Tommyknockers» to new life soon. At least it was announced that a

${ }^{64}$ Perry M.A., McAleer P. Introduction: A More Subtle Macabre. Stephen King's Modern Macabre. Essays on the Later Works / Ed. by M. A. Perry, P. McAleer. Jefferson, North Carolina: McFarland \& Company, 2014. Pp. 1-8.

${ }^{65}$ Greene A. Stephen King: The Rolling Stone Interview. The horror master looks back on his four-decade career. Rolling Stone. October 31, 2014. URL: https://www.rollingstone.com/culture/culture-features/stephen-king-the-rolling-stoneinterview-191529/

${ }^{66}$ Wood R. Stephen King : a literary companion. P. 180.

${ }^{67}$ Baugham M.G. Stephen King (Who Wrote That?). New York : Chelsea House, 2009. P. 82.

${ }^{68}$ Wood R. Stephen King : a literary companion. P. 180.

${ }^{69}$ Magistrale T. Hollywood's Stephen King. P. 15.

70 Greene A. Stephen King: The Rolling Stone Interview. The horror master looks back on his four-decade career.

${ }^{71}$ Perry M.A., McAleer P. Introduction: A More Subtle Macabre. Stephen King's Modern Macabre. P. 1. 
scriptwriter has been tapped. Besides, and it is significant for this article, the novel itself was re-translated into Russian.

There have been several translations of «The Tommyknockers» into Russian before, though not always they adequately corresponded to the source text. The most widely distributed target text appeared in $1997^{72}$ and there was not even the name of a translator there. The holder of the translation copyright, «Cadman» publishing house, doesn't exist today. In 2013 another publishing house, "AST», released the novel in translation by $\mathrm{Yu}$. Moiseyenko and M. Kazanskaya ${ }^{73}$. In the article these two target texts, separated by almost thirty years, will become the sources of the examples of the translators' decisions made when the titles of the novel were reproduced.

\section{2. "The Tommyknockers": \\ title symbolism and the plot in the source and target texts}

H. Strengell states that «the Gothic, myths, fairy tales and literary naturalism together constitute the cornerstone of King's immense popularity» ${ }^{74}$. I will add that in S. King's novels the scheme of symbolic space based on the centuries-old symbols of human culture is drawn with a hundred percent fidelity. No wonder then, that S. King is also no less scrupulous in drawing symbolism of his novels through their titles. In «The Tommyknockers», for instance, a peculiar symbolic architectonics of the original attracts the attention. This architectonics is created by different means, the titles including.

Apart from a foreword and an epilogue, there are three Books in the novel. Each Book contains ten chapters. The titles of the Books together with the subtitles of the chapters form a kind of a prospective-symbolic scheme of the source text as a whole. This scheme will be described later, but to make a further analysis more convenient the list of the source text titles is given below:

«FOREWORD

BOOK I. THE SHIP IN THE EARTH. 1. Anderson Stumbles. 2. Anderson Digs. 3. Peter Sees the Light. 4. The Dig, Continued. 5. Gardener Takes a Fall. 6. Gardener on the Rocks. 7. Gardener

\footnotetext{
${ }^{72}$ Кинг С. Томминокеры / пер. с англ. «Кэдмэн». Москва : АСТ, 1998. 688 с.

73 Кинг С. Томминокеры / пер. с англ. Ю. Моисеенко, М. Казанская. Москва : АCT, 2020. 736 c.

${ }^{74}$ Strengell H. Dissecting Stephen King: from the Gothic to Literary Naturalism. The University of Wisconsin Press, Popular Press, 2005. P. 6.
} 
Arrives. 8. Modifications. 9. Anderson Spins a Tale. 10. Gardener Decides.

BOOK II. TALES OF HAVEN. 1. The Town. 2. 'Becka Paulson. 3. Hilly Brown. 4. Bent and Jingles. 5. Ruth McCausland. 6. Ruth McCausland, Concluded. 7. Beach Jernigan and Dick Allison. 8. Ev Hillman. 9. The Funeral. 10. A Book of Days - The Town, Concluded

BOOK III. THE TOMMYKNOCKERS. 1. Sissy. 2. Gardener Takes a Walk. 3. The Hatch. 4. The Shed. 5. The Scoop. 6. Inside the Ship. 7. The Scoop, Continued. 8. Gard and Bobbi. 9. The Scoop, Concluded. 10. Tommyknockers, Knocking at the Door.

\section{EPILOGUE» ${ }^{75}$.}

At the symbolic level the titles of «The Tommyknockers» fix in themselves the most important, turning points of the plot. For example, the title of the first chapter in the first Book is «Anderson stumbles» ${ }^{76}$ and it indicates a very important event from which the rising action begins: the main she-character trips over the edge of the tommyknockers' spacecraft that emerges from the earth. The incident is symbolically meaningful for several reasons.

Firstly, it is the first signal of a kinetic abnormality: normally Anderson never came across any obstacle there. In human culture a man always experienced the dichotomy 'own / alien' from the 'norm / norm deviation' perspective. Therefore, Bobbi Anderson's stumbling can be symbolically explained as the first marker of the anti-norm, the first intrusion of the alien space of the tommyknockers into the own space of the terrestrials.

Secondly, the incident at the beginning of the rising action is significant in terms of border symbolism. Bobbi fell to the ground and scratched her left cheek «hard enough to bring blood» $\rangle^{77}$. If to treat human's body as a microcosm, the skin then is the border of it. Symbolically any violation of its integrity means the incursion of the alien into the space of the own. The blood shed is extra-meaningful, as it symbolizes the breach of the border. Symbolism of the situation in King's story becomes even more evident, if to remember that in the

\footnotetext{
${ }^{75}$ King S. The Tommyknockers. N.Y.: A Signet Book, 1988. 747 p.

${ }^{76}$ King S. The Tommyknockers. P. 13.

${ }^{77}$ Ibid. P. 16.
} 
'left / right' binary the 'left' relates to the otherworld and is always connected with something unfavourable and sinister, with, chaos, alert ${ }^{78}$.

Thirdly, the afore-mentioned symbolic codes create a context where symbolic contact turns to be possible, as the initial elements of it are present. They are Bobbi's predisposition and the tommyknockers' nonverbal invitation to a contact. It is logical symbolically that Bobbi is induced to strengthen the contact.

The title («Anderson stumbles») performs its prognostic function: through its symbolism, that is unfolded in details in the plot of Book $I$ and the fragment of which has been explained, the title of a chapter predetermines the negative character of the events that are going to happen later, as well as the potential danger threatening the heroine.

Prognostic function the title of the first chapter is actualised not only via symbolism, but via figurative meaning of the key verb in the title too: «to stumble» means also «to commit a grave mistake, to do wrong» ${ }^{79}$. Such interpretation confirms the supposition about the possible development of the plot that has been previously made on the symbolic basis. Bobbi really predestined the death of her own world, having made only one mistake - she began to set the unknown thing free.

The translators from «Cadman» publishing house tried to reproduce the designation of the title. But they failed to transfer the correlation of explicit and implicit planes of meaning. As it has been said above, explicitly the title indicates the physical act of nearly falling over as Bobbi puts her foot down awkwardly. A mistake made by Bobbi is hidden in the implicit meaning of the title and comes up to the surface of narration much later, when the consequences of Bobbi's actions become obvious.

In the target text by «Cadman» the title does not designate a stumble. «Бобби ошибается» ${ }^{80}$ means only that she makes a mistake. Thus, an implicit hint at the future evaluation of the event that happened at the beginning is revealed and shifted into the explicit plane earlier than the author intends to do it. The translators thus jump ahead, lose the symbolic function of a title and weaken its prognostic.

The creators of the new Russian translation of «The Tommyknockers» better understood the polyvalent original title. Their

${ }^{78}$ Biedermann H. Dictionary of Symbolism. Translated by J. Hubert. New York, Oxford: FactsOnFile, 1992. P. 283; Cooper J. C. An Illustrated Encyplopaedia of Traditional Symbols. P. 96.

${ }^{79}$ Collins Online English Dictionary. URL: https://www.collinsdictionary.com/ dictionary/english

${ }^{80}$ Кинг С. Томминокеры / пер. с англ. «Кэдмэн». С. 9. 
version of the title is "Андерсон спотыкается»" ${ }^{81}$. Obviously they managed to find a correspondence that gives the possibility to interpret the target title in several planes similarly to the source text. «Cпотыкаться» in Russian means both «to trip over» and «to make an uncertain pause, a mistake». Hence, the target reader may try to decode the title of the first chapter not only at the explicit level, but at the implicit level too.

One more peculiarity of the titles in «The Tommyknockers» is that they altogether produce a kind of a 'spring effect'. This metaphorical description of the title functions was suggested by I. R. Gal'perin ${ }^{82}$. The scholar meant that a title reveals its sense bit by bit, like coils in a spiral spring. It is exactly what happens in the source text under analysis: the titles are repeated and through this system of repetitions the sense of the titles, as well as the sense of the whole text (including its symbolism) are extracted and gradually deepened. Categories of cohesion, coherence and prospection are also actualised in this way.

Here is the example of such 'spring' (Fig. 1). The title of the ninth chapter from Book I passes into the title of Book II:

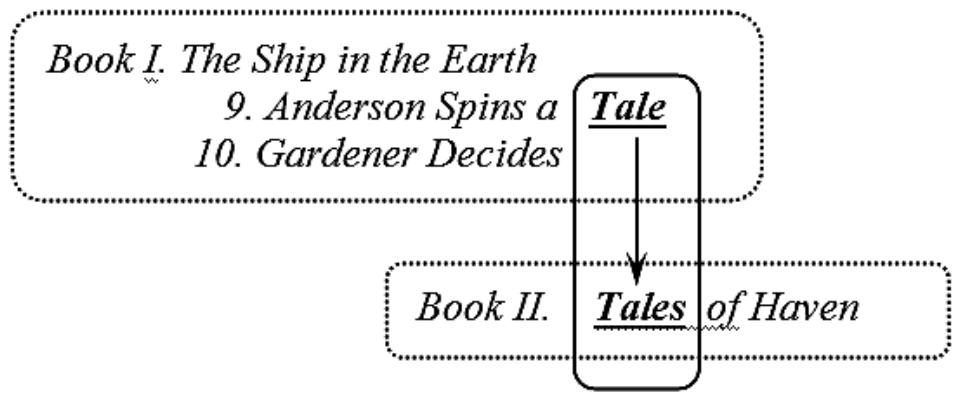

Fig. 1. The example of a 'titles spring coil' in "The Tommyknockers" by S. King

The last word from the title of the ninth chapter («Tale») is repeated in its plural form at the beginning of the title of Book II («Tales») with the title of the tenth chapter between them. The repetition is quite explicable: after Bobbi tells what happened to her, the stories about the Havenites are told. Every story is triggered by what Bobbi has said and

\footnotetext{
${ }^{81}$ Кинг С. Томминокеры / пер. с англ. Ю. Моисеенко, М. Казанская. С. 9.

${ }^{82}$ Гальперин И.Р. Текст как объект лингвистического исследования. С. 133.
} 
done. Implicitly the repetition underlines that the line of fortune is changing: at first this is the change of Bobbi's fate, then the fate of people who live in Haven, and eventually the fate of the entire town.

Obviously, the trigger of all these changes is Bobbi's tale. What happens is that she breaks all symbolical borders which separate her from the world of the alien (for more details see ${ }^{83}$ ) and being completely under the negative influence of that world, she herself is gradually transforming into an alien on the Earth. These transformations are ruining and dangerous, because the tommyknockers, who are pulling Bobbi into their world, are alien not only to the terrestrial space (the middle of the axis mundi where people live), they are alien even to the symbolical otherworld of this terrestrial space, of the universe. In terms of symbols of human culture they are twice marked by 'alienness', being 'alien in alien'. Bobbi turns to be a mediator between the double-alien world of the hostile creatures and the people, who fall under the influence of that anti-world.

Hence, the verb «to spin» in the source title of the ninth chapter. When Bobbi «spins a tale», she tries to persuade the listener (Jim Gardener) that the story is true and she also tries to influence his attitude to the story. The Russian verb «рассказывает» in «Cadman»'s translation («Глава 9. Андерсон рассказывает» ${ }^{84}$ ) doesn't possess such a meaning and relates mostly to a calm accounting of the events.

But Bobbi is not recounting the events. She transfers information and thus induces the listeners to action. The communication goes on not only by means of words, but at the non-verbal level as well. It is abnormal for the inhabitants of the Earth and in this way the influence of the alien word is symbolically strengthened.

The loss of the part of the verb meaning in the target text makes it necessary to reproduce the twice repeated noun «tale» as accurate as possible. Still the translators of «Cadman» don't care about that. Repetition is not reproduced in their target text: «Глава 9. Андерсон рассказывает $\rightarrow$ Книга II. Истории Хейвена» ${ }^{85}$. Consequently, in the target text there is no initial prognostic indication of the interconnection between plotlines and characters of Book I and Book II. A target reader

83 Шама И.Н., Андреева И.А. Символика границы в топографии завязки романа С. Кинга «The Tommyknockers» в оригинале и в переводе. Вісник ЗДУ. Філологічні науки. 2000. № 1. С. 219-222.

${ }^{84}$ Кинг С. Томминокеры / пер. с англ. «Кэдмэн». С. 149.

${ }^{85}$ Ibid. C. 149, 201. 
may conclude, that the stories of the Havenites are not caused by the story told by Bobbi, though the translators try to compensate the loss: the title of Chapter 10 (Book II) is reproduced with an addition in the target variant: «The Town, Concluded» ${ }^{86} \rightarrow$ «История города. Заключение» ${ }^{87}$. An interesting solution, but it results in the loss of the connection between chapters 1 and 10 in this Book, which is also meaningful for the source text (about it - see below).

In $2013 \mathrm{Yu}$. Moiseyenko and M. Kazanskaya go a different way in their translation. They also omit «spins» in the target title, but contrary to «Cadman» they preserve the noun: «Глава 9. Рассказ Бобби Андерсон» ${ }^{88}$. Book II then is entitled synonymically to chapter 9: «Истории Хейвена» 89 . Explicit meaning of the repetition and its implicit hint at the course and the effect of the evens are reproduced: «история» and «рассказ» are synonyms in Russian.

As for the implicit meaning of «spins», it is not reproduced here either. The problem is presumably in the absence of a Russian verb with the same set of meanings, though they might have tried to add an adverb or adjective, or found some other verb for compensation. I may suggest, for example, the following variant for the 'title spring': «Глава 9. Убедительная история Андерсон $\rightarrow$ Книга II. Истории Хейвена».

The 'spring effect' reveals itself also in one more peculiar mode of entitling. Very often S. King uses the technique of unfinished chapter that is continued later. Inevitably he is to reflect this way of composing in the titles as well. Here is the example from Book I (Fig. 2):

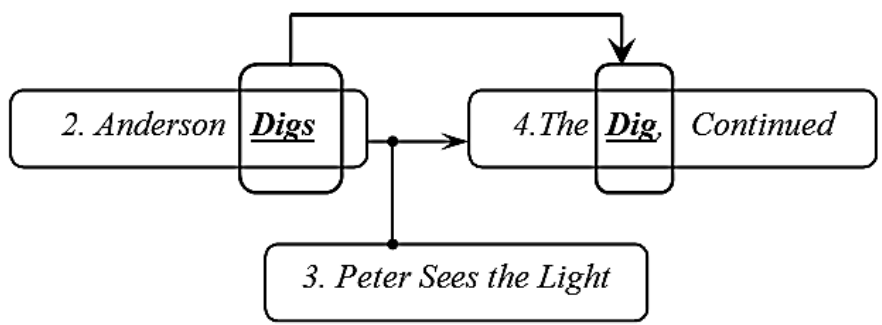

Fig. 2. The example of the 'titles spring' and the divided chapter in Book I

\footnotetext{
${ }^{86}$ King S. The Tommyknockers. P. 444.

${ }^{87}$ Кинг С. Томминокеры / пер. с англ. «Кэдмэн». С. 408.

${ }^{88}$ Кинг С. Томминокеры / пер. с англ. Ю. Моисеенко, М. Казанская. С. 162.

${ }^{89}$ там само. С. 217.
} 
In view of the symbolic interpretation of the source text it's quite interesting to examine the titles of those chapters that are 'wedged' between the preceding and following parts of the virtually integral whole. It's quite noticeable that the titles of the 'wedged' chapters nominate as a rule the turning and decisive moments not only in the plotline they are connected with, but in the entire novel.

In Book I the 'wedged' chapter is called «3. Peter sees the light ${ }^{90}$. Peter is Bobbi's dog. A dog is a symbolically marked animal. Archaic symbolism appreciates a dog as a mediator between one's own and alien space. Therefore, it is Peter who is the first to see the strange alien light and unmistakably feel its potential danger. The hostile nature of the light is obvious for a dog and this undoubted 'knowledge' is reflected in a definite article («the light»). It is not reproduced in the target text, because the article is an equivalent-lacking unit of translation from English into Russian: «Глава 3. Питер видит свет» ${ }^{91}$. As a result the Russian title can be interpreted in two ways: 1) Peter sees $\boldsymbol{a}$ light, or 2) Peter sees the light. The first variant is not adequate as it presupposes that the dog may see any kind of light and this light is not unusual.

Incidentally, Peter is not only the first to see the light, but also the first to disappear, leaving Bobbi alone without any restraint on earth (about it - see 4.3. "The Tommyknockers»: biblical symbolism in the source and target titles).

One more instance of the set of titles for the divided chapters is in Book III (Fig. 3):

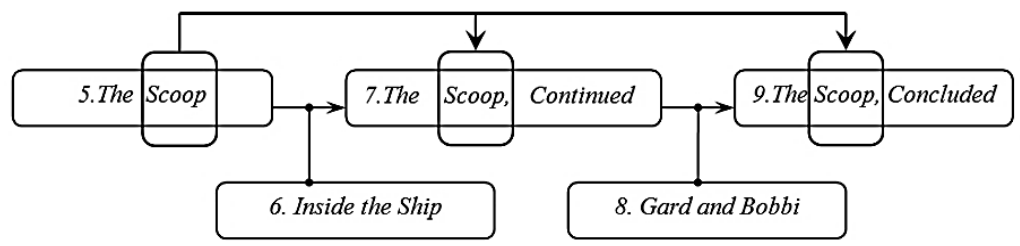

Fig. 3. The example of the titles for the divided chapter in Book III

Thematically chapters five, seven and nine are the parts of one long chapter under the title «The Scoop» that is separated by two 'wedged'

\footnotetext{
${ }^{90}$ King S. The Tommyknockers. P. 45.

91 Кинг С. Томминокеры / пер. с англ. «Кэдмэн». С. 31 ; Кинг С. Томминокеры / пер. с англ. Ю. Моисеенко, М. Казанская. С. 40.
} 
chapters entitled correspondently «6. Inside the Ship» and «8. Gard and $B o b b i \gg)^{92}$. And again these two 'wedged' titles point to the most tensed moments in the Book. In the sixth chapter, as the title indicates, the heroes finally entered the ship of the tommyknockers. Having opened it, the characters distort the last border between the two worlds - terrestrial and alien. Thereafter the plot is impetuously striving for the denouement and leads to the open confrontation between the main characters - Bobbi Anderson and Jim Gardener.

It's remarkable that the title of the eighth chapter is the only one where the characters are called by their short names: «8. Gard and Bobbi» ${ }^{93}$. Up to this chapter only full forms of the family names (Gardener and Anderson) were used in the titles. Symbolically any family name establishes the link between a person and his / her ancestors $-c f$. ancestor worship and ancestors cult in the pre-Christian world ${ }^{94}$. For Jim Gardener and Roberta Anderson it means that they are protected by their terrestrial kin, including the departed ancestors, and the surnames provide the link and protection until the characters follow the rules of the norm accepted in their own world.

Regarding this, the changes of the names in the title may signal about some crucial alterations in the characters themselves. In the previous chapters they both were called by their family names, but now only short first name is left for Bobbi as she lost her terrestrial roots, look and essence. The ancestors are not protecting her any longer. The situation is different in case of Jim Gardener. He managed to save at least a part of his belonging to the Earth. Therefore he hadn't lost the link with his ancestors completely. That's why the part of his family name (Gard) remains with him. The characters thus are symbolically excluded from the terrestrial own world (Bobbi - completely, Gard - partly). And only after that «The Scoop»-chapter can come to its ending : «9. The Scoop, Concluded $\gg$.

The unlikeness of the eighth chapter title to the rest of the nominal, personalized titles is differently reproduced in the target texts. The

${ }^{92}$ King S. The Tommyknockers. Pp. 585, 602, 623, 636, 652.

${ }^{93}$ Ibid. P. 636.

${ }^{94}$ Hardacre H. Ancestors: ancestor worship. Encyclopedia of Religion / Ed. by L. Jones. Detroit, MI: Thomson Gale, 2005. Vol.1. Pp. 320-325; Levinson D. Religion: a cross-cultural encyclopedia. Santa Barbara, California; Denver, Colorado; Oxford, England: ABC-CLIO, 2011. Pp. 3-6; Monaghan P. The encyclopedia of Celtic mythology and folklore. New York : Fact On File Inc., 2004. P. 17.

${ }^{95}$ King S. The Tommyknockers. P. 652. 
«Cadman» translators commonly transcribe the proper names and use loan translation when word-combinations are to be reproduced. In case of the title of the eighth chapter from Book III it results in adequate translation.

$\mathrm{Yu}$. Moiseyenko and M. Kazanskaya chose a different tactics. They opt for reproducing the meaning of any title to the most possible extent. Accordingly, they admit the use of translation transformations and it sometimes changes the symbolic structure of the title system in the target text. Thus, the uniquity of the eighth title in Book III («8. Gard and Bobbi») is not reproduced only because the translators specified the title of Chapter 9 from Book I («Anderson Spins a Tale»), adding a short name of the heroine to it: «Глава 9. Рассказ Бобби Андерсон» ${ }^{96}$. The variant influences the architectonics of the entire target text: an addition of a short name in Book I precludes the symbolic interpretation of the link between the character and her ancestors in Book III.

But let's return to the three chapters entitled as «The Scoop». In terms of symbolic interpretation the title starts actualizing some extra semes. This is typical for symbols, as they are attributed with the ability to gain new meanings in the process of their evolution and nevertheless they don't lose all previously possessed meanings. In case of the chapters, joined by «The Scoop» in the titles, two planes of interpretation are possible. Firstly, the exceptionality of the event - at long last, the characters find the entrance to the spacecraft. Hence, the title - «The Scoop», that means "an exciting news story which is reported in one newspaper or on one television programme before it appears anywhere else» ${ }^{97}$. Secondly, one more, rare meaning of «scoop» is explicitized: it can be $\left\langle a\right.$ hollow-space ${ }^{98}$ and it is the precise description of a place whereto the main events of the original plot are moved. In both translations into Russian only one plane of interpretation is possible - an extraordinary event : «Сенсация»" ${ }^{99}$, «Сенсация, журналистское раследование» ${ }^{100}$. The translators reproduce the most frequently used meaning and thus, to the target readers' regret, the title loses its ambiguity and leads to a less adequate translation.

\footnotetext{
${ }^{96}$ Кинг С. Томминокеры / пер. с англ. Ю. Моисеенко, М. Казанская. С. 162.

${ }^{97}$ Collins Online English Dictionary.

98 Ibid.

${ }^{99}$ Кинг С. Томминокеры / пер. с англ. «Кэдмэн». С. 541.

${ }^{100}$ Кинг С. Томминокеры / пер. с англ. Ю. Моисеенко, М. Казанская. С. 571.
} 


\section{3. "The Tommyknockers": biblical symbolism in the source and target titles}

Symbolism in King's body of fiction is marked by a kind of hybridity: one and the same piece of fiction can bring into play both archaic symbols of pre-Christian times and latter biblical symbols. Such twofold nature of symbolism proves once again that symbolism can reveal the worldview of a source text and this worldview is deeper and more reliable than any other levels of text-interpretation can describe.

In «The Tommyknockers» there are a lot of ancient archaic symbols that existed long before the world religions appeared. These symbols are widely used, though they are not directly mentioned contrary to biblical symbols that are used explicitly, deliberately and thus influence greatly the plot structure of the source text as well as its symbolic structure.

The titles in «The Tommyknockers» are also under the influence of biblical symbolism. The novel is divided into three main parts. Every part is called «Book» (cf.: the texts of a biblical canon are usually called «books», e. g. the Books of the Old and New Testament, the Book of Revelation, the Book of Judges, etc.). Both Russian target texts are divided into three books too: «книга $1 »$, «книга $2 »$, «книга $3 »{ }^{101}$. In this way the translators allude to the Russian translation of the Bible, where the correspondence «книга» is used.

Structurally the novel reminds of the Holy Writ all the time. Every Book is divided into chapters that are then split into parts similarly to how the Bible is divided into verses. Interestingly, that King does not use the noun «chapter» in his novel. He prefers numbers only, e. g.: «1. The Town ${ }^{102}$ or $« 4$. The Shed ${ }^{103}$. Nevertheless, in the target texts (both by «Cadman» and by Yu. Moiseyenko and M. Kazanskaya) an addition is used. Everywhere the number is paired with the noun «глава»: «Глава 1. Город» ${ }^{104}$ or «Глава 4. Сарай» ${ }^{105}$. The addition is acceptable. Being more concrete, it relates closer to the biblical division and makes the biblical symbolism more evident.

The biblical story of creation is reflected in the title of Book II, though in «The Tommyknockers» it looks more like the anti-myth, being

101 Кинг С. Томминокеры / пер. с англ. «Кэдмэн». С. 7, 201, 479 ; Кинг С. Томминокеры / пер. с англ. Ю. Моисеенко, М. Казанская. С. 9, 217, 507.

102 King S. The Tommyknockers. P. 225.

103 Ibid. P. 561.

104 Кинг С. Томминокеры / пер. с англ. «Кэдмэн». С. 203 ; Кинг С. Томминокеры / пер. с англ. Ю. Моисеенко, М. Казанская. С. 220.

105 Там само. С. 548. 
opposite to the common story. Book II has seven chapters named after people from Haven (cf. seven days of Creation). But in S. King's version the whole biblical story of Creation changes its axiological coordinates. Every character is eponymous for his /her chapter and makes the triumph of the alien space of the tommyknockers closer. But if in the Bible every day is marked by birth and life, in King's story every chapter is marked by the real or symbolical death of a character, by his /her transition into the alien space. In this view quite natural is the title of the eighth chapter: «8. The Funeral» ${ }^{106}$.

All the names of the Havenites in the titles are reproduced rather successfully. They are transcribed and transliterated according to the existing patterns. The problem emerges when the title of the sixth chapter is to be reproduced.

The chapter is the continuation of the previous one: «5. Ruth MacCausland ${ }^{107} \rightarrow\left\langle 6\right.$. Ruth MacCausland, Concluded ${ }^{108}$. These two chapters are two parts of one whole. This mode of structural division of the source text titles, when the story remains unfinished and then continued right after the starting part or in several parts, has already been formerly described. Taking into consideration the significance of such mode for the whole structure of the titles in the source text, the break of this structure in the target text leads to a deviation from the source text: «Гава 5. Рут Маккосланд» $\rightarrow$ «Глава 6. Рут Макккосланд принимает решение» ${ }^{109}$.

It's not a mistake, though this variant of the target text can not be accepted as the adequate one. The matter is that the verb «to conclude» has several meanings and at least three of them are involved into the functional context of the title. Explicitly it marks the ending of the previous chapter and the decision that Ruth makes, but implicitly one more meaning appears. Symbolically the title of the sixth chapter indicates that Ruth MacCausland's path of life comes to its end. The translators from «Cadman» group didn't try to find the verb with the same number of associations in the Russian language. Their correspondent target title means only «to decide»: «6. Рут Маккосланд принимает решение» ${ }^{110}$. Thus, the target title does not only narrow the

\footnotetext{
${ }^{106}$ King S. The Tommyknockers. P. 401.

107 Ibid. P. 286.

108 Ibid. P. 318.

${ }^{109}$ Кинг С. Томминокеры / пер. с англ. «Кэдмэн». С. 258, 284.

${ }^{110}$ Ibid. C. 289.
} 
interpretative possibilities, but changes the logic of connections between the whole set of titles in the novel. Instead of being linked with chapter 5, the target chapter 6 appears to be strongly linked with chapter 10 of Book I, because it repeats its title, though relates it to another chapter (Fig. 4):

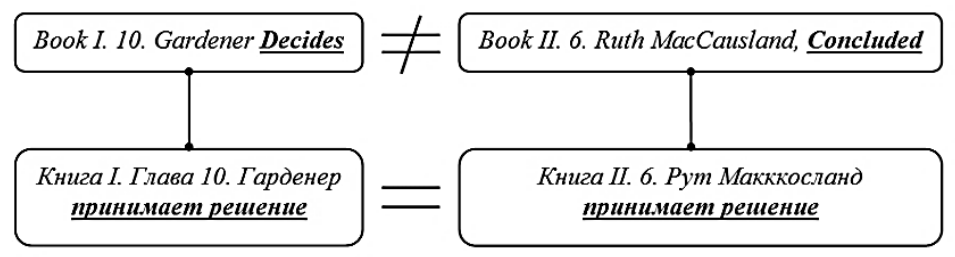

Fig. 4. The example of the destruction of the title logic in the Target Text

The translators create some additional link between the characters (Gardener and Ruth MacCausland) and as it is done by means of the titles, it forms false expectations for the target reader. Besides, this kind of repetition of the target title means that these two characters are closely related to one another, which is not true: Jim Gardener is close only to Bobbi, while Ruth has her own close relations.

Contrary to «Cadman», Yu. Moiseyenko and M. Kazanskaya retain the practice of leaving the chapter unfinished with its further continuation: «6. Ruth McCausland, Concluded» ${ }^{111} \rightarrow$ «лава 6. История Рут Маккосланд, окончание» ${ }^{112}$. But they add the noun «история» into the target title. On the one hand, it helps to preserve the implicit indication of the end of Ruth's life: «история» can be understood as the «life story» of Ruth MacCausland. But on the other hand, the translators are caught in the same trap as «Cadman» was caught. It is again connected with the architectonics of the whole set of titles in the source text. What is broken this time is the 'spring effect' described afore in the article. The addition in the target title attaches the title of chapter 6 to the 'spring' that is based in the source text on the noun «tale». The 2013 translation gets the extra-repetition of the key word in the titles: «Глава 9. Рассказ Бобби Андерсон» ${ }^{113}-$ «Книга

${ }^{111}$ King S. The Tommyknockers. P. 31.

${ }^{112}$ Кинг С. Томминокеры / пер. с англ. Ю. Моисеенко, М. Казанская. С. 311.

113 Там само. С. 162. 
вторая. Истории Хейвена» ${ }^{114}$ - «Глава 6. История Рут Маккосланд, окончание» ${ }^{115}$. As a result, apart from Bobbi, one more symbolic centre of influence on the events appears in the target text, and this new centre is even stronger than that connected with Bobbi, because for the title of the chapter about Ruth the translators repeat the same correspondence as for the title of Book II («история»), while the chapter about Bobbi is entitled in the target text by the synonymous noun «рассказ».

Such translators' decision leads up to one more change of the architectonics of the target text in comparison with the source one: the connection between the unfinished chapter 5 and its conclusion in chapter 6 is broken, because the target text doesn't save the unity and succession of entitling (compare Fig. 5 and Fig. 6):

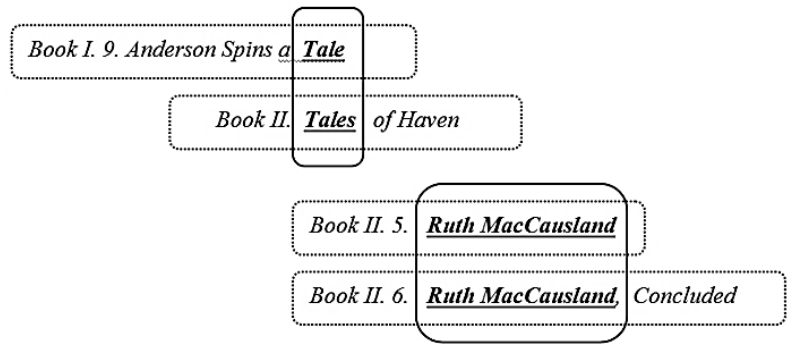

Fig. 5. The example of the 'titles springs' in the source text: Books I \& II

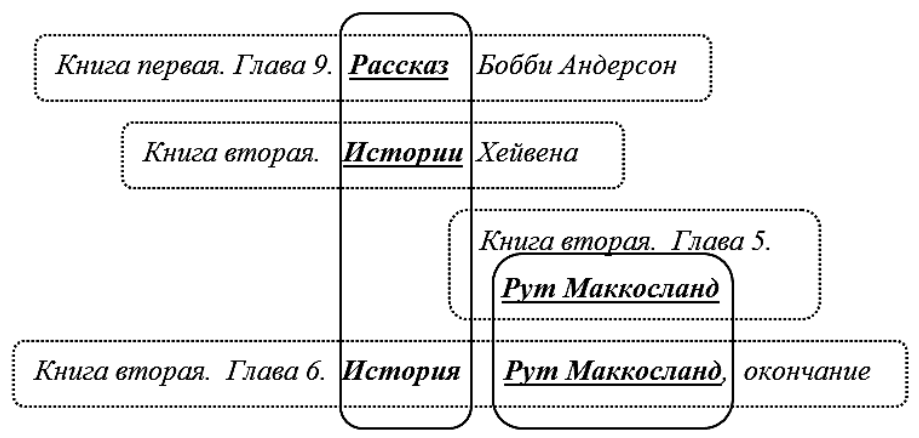

Fig. 6. The example of the 'titles springs' in the target text: Books I \& II

${ }^{114}$ Кинг С. Томминокеры / пер. с англ. Ю. Моисеенко, М. Казанская. С. 217.

115 Там само. С. 311. 
In my view, it's better to reject the addition and to use the loan translation: «Рут Макккосланд, окончание».

The reversion of the Biblical legend is also revealed in the title of the final tenth chapter in Book II: «10. A Book of Days» ${ }^{116}$. The title is fraught with 'poliallusion' (the term is mine - I. Sh.). On the one hand, it alludes to the Bible itself («the Book of Books»)). On the other hand, it can allude to «the end of days». This chapter is really apocalyptical for the residents of Haven: they are fully subordinate to the power of the alien symbolic space, i. e. they are symbolically dead. One more allusion can also be traced in the title: the association with «the Book of Fate». In chapter 10, likewise in "the Book of Fate», the fate of all seven main characters, as well as the fate of the whole town, is sealed.

But even more symbolically significant is the allusion to the «Book of Life», that is the book where the name of every person who is saved on Judgement Day is recorded, while the rest, «not found written in the Book of Life» will be «cast into the lake of fire» (Rev $20: 15$ ). In «The Tommyknockers» all the Havenites and the forest around the town die in flames.

Unfortunately, when reading the Russian translation by «Cadman» «Глава 10. Книга дней» ${ }^{117}$ - the target readers will not be able to comprehend all the allusions of the title. It will not be possible to grasp all the intra-textual relations in the target text as well. The readers of the 'Russian King' can have associations with the Book of Books, the Book of Life and the Book of Fate. But the allusion to «the end of days» can not appear in the target text. However, it's not the translators' fault. The matter is that in the first three cases (the Book of Books, the Book of Life and the Book of Fate) the key word «book» is preserved in the target culture and language. Being the key marker, it helps the triple allusion appear in the target text: «книга книг», «книга судеб», «книга жизни». The situation is different with «the end of days». The marker of the allusion in the target text is «days» («A Book of Days»), but in Russian «the end of days» is known as «конеи света». If in the source text both words in the title are the markers of the allusion, in the target text only one is left («книга). The loss of the second one seems to be inevitable.

In $2013 \mathrm{Yu}$. Moiseyenko and M. Kazanskaya decided to weed out the complex poliallusion from their target text. Presumably, they took the title («A Book of Days») as the chronology of the events that happen in

116 King S. The Tommyknockers. P. 444.

${ }^{117}$ Кинг С. Томминокеры / пер. с англ. «Кэдмэн». С. 408. 
the original. Hence, their correspondence to the title of the tenth chapter is «Глава 10. Хроника событий» ${ }^{118}$. Regarding the explicit meaning of the English title, there is no strict objection to their decision. Such translation correlates with the inner structure of the chapter that is written in the form of a chronicle or a diary, where the dates are indicated and then everything that happened at this date is described. Though it's a regret that the target readers are deprived of the possibility to decipher the source 'poliallusion' and to comprehend the integral meaning of the title and its symbolism.

\section{4. "The Tommyknockers": symbolism of names in the source and target titles}

David Lodge in "The Art of Fiction» devoted the entire chapter to names in a literary text. There he states that «in a novel names are never neutral» ${ }^{119}$ and illustrates «an odd and interesting status» of proper names by the following observation: «We don't expect our neighbour Mr. Shepherd to look after sheep, or mentally associate him with that occupation. If he is a character in a novel, however, pastoral and perhaps biblical associations will inevitably come into play»> ${ }^{120}$.

It is exactly what happens to names in a literary text especially when their symbolism is involved into text-interpretation. Biblical symbolism is meaningful for «The Tommyknockers». Apart from the afore-given examples, the symbolism reflects itself in the titles that contain the names of the source text characters. All the names in the novel prove the idea of P. Florensky, who insisted that no onomathet choose the name occasionally. P. Florensky also stressed that every name «predestines personality and defines the ideal boundaries of his / her life» ${ }^{121}$. Consequently, all the names mirror the authors' intents and all the names pre-program the heroes' behaviour and thus influence the plot development, because characters may or may not live up to the program that their names dictate. David Lodge is absolutely right when he says that «the naming of characters is always an important part of creating them» ${ }^{122}$.

118 Кинг С. Томминокеры / пер. с англ. Ю. Моисеенко, М. Казанская. С. 433.

${ }^{119}$ Lodge D. The Art of Fiction. P. 37.

${ }^{120}$ Ibid. P. 36.

121 Флоренский П.А. Имена. Сочинения. Москва : Эксмо-пресс ; Харьков : Фолио, 1998. С. 511.

${ }^{122}$ Lodge D. The Art of Fiction. P. 37. 
In «The Tommyknockers» there are a lot of interesting examples of how the name of a character correlates with the story itself. For instance, Peter, the dog, is the first living creature on the Earth whose body was occupied by a tommyknocker. He is also a mediator between Bobbi and the aliens, and he is the 'key' that opens the secret door of the spacecraft for Bobbi and later for Gard. The door that sets the evil free.

The name evokes the association with Peter the Apostle, who was named by Jesus and to whom Christ said: «Thou art Peter; and upon this rock I will build my church; and the gates of hell shall not prevail against it. And I will give unto thee the keys of the kingdom of heaven» (Matthew $16: 18-19$ ). Peter the dog seems to be the antipode to Peter the Apostle, likewise the keys in «The Tommyknockers» are not the keys from Paradise, but from Hell. It gives one more argument to the hypothesis that the biblical story turns to its opposite in the novel by S. King.

The allusion to Saint Peter is less obvious in translation, because in both target texts the name is transcribed («Питер»), while the Russian variant of the hagionym has its traditional equivalent «Пёmp». It's a conventional practice, when one and the same English name has two variants of translation, the choice of which depends on the context, e. g. «Michael» can be reproduced as «Maйкл» (a mundane name) or «Михаил» (the saint's name); «Andrew» also has two correspondences «Эндрю» (a mundane variant) and «Андрей» (a hagionym). The translators of «The Tommyknockers» opt for the foreignisation of the dog's name, but it leads up to the lessening of the name symbolism. Really regrettable is the inevitability of losses in case of divergence of the mundane and biblical forms of the name in the target language.

This is only one and brief example of how name symbolism helps understand the implicit plotlines. But in the source text the number of such instances is much more. Further the attention will be concentrated on the names of two main characters: Roberta (Bobbi) Anderson and James (Jim) Gardener.

English family name «Anderson» is etymologically correlated with the name of one of the Twelve Apostles - St. Andrew ${ }^{123}$, who was Jesus's first disciple and therefore in the Orthodox tradition is referred to as Andrew the First-Called. But if in the Bible Andrew the Apostle was the first converted to faith and was called to serve the God and good, in «The Tommyknockers» Bobbi Anderson, vice versa, is the first human terrestrial converted to alien evil. It is Bobbi Anderson who discovers the

123 Рыбакин А.И. Словарь английских личных имён. Москва : Астрель ; ACT, 2000. C. 36. 
tommyknockers' spacecraft, and it is she who brings the Havenites under the influence of the aliens and then under subordination to them.

In the New Testament St. Andrew and his brother St. Peter were called by Jesus who said: «Follow me and I will make you fishers of men» (Mark $1: 17$; Matthew $4: 19$ ). They followed Jesus in his salvific mission. In «The Tommyknockers» Bobbi Anderson with Peter, her dog, also catch men, however, not for salvation, but for hell. The main character thus doesn't live up to the path that her name pre-programs. Hence, her death at the end gives one more argument for the assumption that S. King's novel can be comprehended as the anti-Bible.

The name of Bobbi's partner - Jim Gardener - is also symbolically connected with the Biblical myth. But contrary to Bobbi, who fails to fulfil the 'program' of her surname and dies partly because of that failure, Jim on the whole follows the symbolic path of his name.

«Jim» is a diminutive for «James». The latter in its turn is the English form of «Jacob», the name of the biblical apostle ${ }^{124}$. Jacob is considered to be the personification of a tribal group ${ }^{125}$. Jim Gardener symbolically embodies all the terrestrials, who defend their own space from the encroachments of the evil aliens.

Etymologically the name of Jacob can be deciphered as «the one who follows on the heels» ${ }^{126}$. Jim does follow on the heels of the tommyknockers, revealing thus Bobbi's secret and the danger that comes from her. But the name of Jacob also means «may god help and protect» ${ }^{127}$. Jim's actions are directed just to keep his own symbolic space safe and integral, to protect the Earth from the tommyknockers.

In this perspective Jim's surname is also meaningful. Literally «Gardener» means «the one who works in the gardens». The garden is symbolically opposed to the forest in the same way as the own is opposed to the alien, the good to the evil, the order to the chaos ${ }^{128}$. Jim

${ }^{124}$ Behind the Name. URL: https://www.behindthename.com/name/james

125 Иванов Вяч. Вс. Иаков. Мифы народов мира : в 2-х т. / гл. ред. С.А. Токарев. Москва : Сов. энциклопедия, 1987. Т. 1. С. 476.

126 Рыбакин А.И. Словарь английских личных имён. Москва : Астрель ; ACT, 2000. C. 112.

127 Behind the Name. URL: https://www.behindthename.com/name/james ; Иванов Вяч. Вс. Иаков. Мифы народов мира : в 2-х т. / гл. ред. С.А. Токарев. Москва : Сов. энциклопедия, 1987. Т. 1. С. 474.

128 Bruce-Mitford M. Signs \& Symbols: An Illustrated Guide to Their Origins and Meanings. London, New York, Munich, Melbourne, Delhi: Dorling Kindersley Limited, 2008. Pp. 244-249; Cirlot J.E. A Dictionary of Symbols. 2nd edition. Translated from Spanish by J. Sage. London: Routledge, 1971. P. 115. 
represents the first poles of the enumerated dichotomies. Presumably, it is that main reason for which, on the one hand, he is saved, and, on the other hand, it is he who saves the Earth.

Unfortunately, prognostic of the names in the source text titles, likewise their biblical and other symbolic senses, remains 'hidden' from the target text readers. And, just like in case of the title of the tenth chapter from Book II, the translators mustn't be blamed for that. Proper names are conventionally transcribed or transliterated in the target language, the more so, when the names of the characters (eponyms including) are the nominative anthroponyms, commonly used in English. In the source text, being included into a number of contexts, such names may 'awake' their etymology and symbolism. It makes them produce allusions, associations and construct complicated intertextual relations. But in the target language the etymology of such names cannot be restored automatically, though the lack of interpretational possibilities can be compensated for the target readers. The translators could give commentaries, explain the symbolic layers of interpretation either in a foreword or afterword to the target text, or in the translators' notes. It is also a way out, if a glossary of names is given, in which all necessary nuances of name symbolism are explained.

\section{CONCLUSIONS}

Though only some selective examples have been analysed in the article, it is possible to state that a problem of interpreting and translating literary titles seems to be not only excessively challenging and important, but it is virtually inexhaustible. The unique status of a title in a literary text, as well as a peculiar attention to a title in the process of translating emerge from different factors. Firstly, it is a complex dialectical nature of a title that is both autosemantic and synsemantic element of a text. Secondly, it is a multitude of obligatory functions that a literary title performs in its text. Thirdly, it is the ability of a title to actualize practically all textual categories.

Symbols in a literary text expose the source text characterology, specify its chronotope, plot, architectonics, etc. They can construe a literary text at some primal levels and thus can't but be reflected in the system of text titles.

Symbols of culture may become titles or may be included into a title as its part and, consequently, help comprehend deeper meaning of a text through grasping the genuine intention of the source text author, discern 
those relations of textual elements that are less / not evident in the process of cursory reading of a text.

When a literary text is interpreted symbolically, all the hallmarks of a title become more distinct and the significance of a title increases manifold, because a title turns into 'a key' to deciphering symbols of this very text. Having interpreted the original title at a symbolic level, among the multitude of senses a translator can single out those ones which are principal for a source text.

The adequacy of translation as a whole greatly depends on the ability of a translator to attain the target titles that are isofunctional to the complexity of the nuances of meaning of the source titles, especially the nuances that are connected with the interpretation and decoding of symbols of the source culture. The role of a translator in this process is undeniably important that is proved by the analysis of the title symbolism in «The Tommyknockers» by S. King and in the translations of the novel into Russian.

The topos of «The Tommyknockers» by S. King is based on the ancient symbols of human culture. It is obviously reflected in the titles of the novel. At the symbolic level they fix the turning points of the plot through the 'own / alien' and 'norm / norm deviation' binaries. The 'left / right' binary helps reveal the border symbolism, the symbolism of the contact and situation in the source text. The symbolic dichotomies also provide the polyvalence and the prognostic of the titles at the symbolic level.

One more peculiarity of the titles in «The Tommyknockers» is that they altogether produce a kind of a 'spring effect' through the system of repetitions. In this way the sense of the titles, as well as the sense of the whole text (including its symbolism) are extracted and gradually deepened. Categories of cohesion, coherence and prospection are also actualised in this way.

Symbolism in King's novel is marked by the hybridity, when both archaic symbols of pre-Christian times and biblical symbols are brought into play. In «The Tommyknockers» the ancient archaic symbols are widely used, though they are not mentioned directly contrary to biblical symbols that are used explicitly, deliberately and thus influence greatly the plot structure of the source text as well as its symbolic structure.

The titles of the source text are also under the influence of biblical symbolism, though «The Tommyknockers» looks more like the antimyth. The reversion of the Biblical legend is reflected in the axiological coordinates that are changed into their opposites. 
When reproducing title symbolism the translators may face some challenges. The analysis revealed some typical translation shortcomings. The translators:

- try to reproduce the designation of a title, but fail to transfer the correlation of explicit and implicit planes of meaning, which is exceptionally important for the symbols;

- do not decode the polyvalent symbolic title at all its levels and forget that in terms of symbolic interpretation the title starts actualizing some extra semes, as the symbols are attributed with the ability to gain new meanings in the process of their evolution, but not to lose all previously possessed meanings. Thus, the translators weaken the prognostic function of the source text symbols;

- do not comprehend the symbolic meaning of the title in connection with the plot of the source text and its characters, because the translators do not catch the whole set of symbolic binaries involved into the title meaning;

- ignore the name symbolism and the fact that all the names mirror the authors' intents, pre-program the characters' behaviour and thus influence the plot development. Thus, the changes of the names in the title may signal about the alterations in the characters themselves.

For a translator every of these factors may be challenging, but the most important task is to preserve the integrity and complex relations between a title and its text. The task demands a lot of attention to details and nuances of such relations. In this perspective the stage of pre-translation analysis of the source text and its close reading becomes very significant.

The interpretation of a source text by its translator should draw the objective 'map' of senses of a source text in all their interrelations and interconnections. It can be done if interpretation is based on the symbols of human culture that are inevitably present in any text of fiction born by this culture.

All that leads to the conclusion that when a translator deciphers symbols of a source text, including the title symbolism, s/he is led to the understanding of deep hidden meaning of an original that is difficult to be caught when the original is read cursory. Hence, a translator gets the possibility to avoid failures in the process of translating.

\section{SUMMARY}

The article aims to expose a literary title as a part of the symbolic language of a literary text. For a translator the most important task is to preserve the integrity and complex relations between a title and its text. The assumption is made that literary titles can be adequately reproduced only if a 
translator comprehends all the nuances of title symbolism. It leads to the deep understanding of the hidden senses of an original that are difficult to be caught in cursory reading. Hence, a translator gets the possibility to avoid failures in the process of translating. The assumption is exemplified by the titles from «The Tommyknockers» by Stephen King in comparison with its Russian translations published in 1997 and 2013.

\section{References}

1. Аверинцев С.С. Символ художественный. София - Логос. Словарь. Киев : Дух і Літера, 2001. С. 155-161.

2. Багдасарьян Н.Г. Язык и культура. Культурология / под ред. Н.Г. Багдасарьян. Москва : Высшая школа, 1998. С. 114-131.

3. Белова А.Д. Универсальное и идиоэтническое в языках на фоне мировых тенденций глобализации и унификации. Науковий вісник кафедри ЮНЕСКО Київського державного лінгвістичного університету (ЛІНГВАПАКС- VІІІ). Серія «Філологія. Педагогіка. Психологія». 2000. Вип. 3А. С. 61.

4. Галь Н.Я. Слово живое и мёртвое: Из опыта переводчика и редактора. Москва : Время, 2007. 592 с.

5. Гальперин И.Р. Текст как объект лингвистического исследования. Москва : КомКнига, 2007. 144 с.

6. Домашнев А.И., Шишкина И.П., Гончарова Е.А. Интерпретация художественного текста. Москва : Просвещение, 1988. 298 с.

7. Есакова М.Н. Межкультурная асимметрия как переводческая проблема. Вестник МГУ. Серия 19. Лингвистика и межкультурная коммуникаиия. 2000. № 2. С. 91-99.

8. Иванов Вяч. Вс. Иаков. Мифы народов мира : в 2-х т. / гл. ред. С.А. Токарев. Москва : Сов. энциклопедия, 1987. Т. 1. С. 474-476.

9. Казакова Т.А. Художественный перевод: в поисках истины. Санкт-Петербург : СПбГУ, 2006. 224 с.

10.Кинг С. Томминокеры / пер. с англ. «Кэдмэн». Москва : АСТ, $1998.688 \mathrm{c}$.

11.Кинг С. Томминокеры / пер. с англ. Ю. Моисеенко, М. Казанская. Москва : АСТ, 2020. 736 с.

12.Комиссаров В.Н. Теория перевода (лингвистические аспекты). Москва : Высш. шк., 1990. 253 с.

13.Кухаренко В.А. Интерпретация текста. Москва : Просвещение, 1988. 192 с.

14. Лукин В.А. Художественный текст: основы лингвистической теории и элементы анализа. Москва : Ось-89, 1999. 192 с. 
15.Новикова М.А. Эквивалентность и адекватность переводов: жанровый аспект. Коммуникативная направленность текста и его перевод. Киев, 1988. С. 4-6.

16.Новикова М.А., Шама И.Н. Символика в художественном тексте. Символика пространства (на материале «Вечеров на хуторе близ Диканьки» Н.В. Гоголя и их английских переводов) : учебное пособие. Запорожье : Акцент Инвест-трейд, 2013. 212 с.

17.Рыбакин А.И. Словарь английских личных имён. Москва : Астрель ; АСТ, 2000. 224 с.

18. Тураева 3.Я. Лингвистика текста: (Текст: структура и семантика). Москва : Просвещение, 1986. 127 с.

19. Тутатина Е.А. Заглавие книги: прагматика, поэтика и эволюция. Неофилология. 2019. № 5(19). С. 349-356.

20.Урнов Д.М. «Живое описание» (Гоголь и Диккенс). Гоголь и мировая литература / отв. ред. Ю.В. Манн. Москва : Наука, 1988. C. $18-49$.

21.Флоренский П.А. Имена. Сочинения. Москва : Эксмо-пресс ; Харьков : Фолио, 1998. С. 449-662.

22. Чернявская В.Е. Лингвистика текста : Поликодовость, интертекстуальность, интердискурсивность. Москва : ЛИБРОКОМ, 2009. $248 \mathrm{c.}$

23. Чуковский К.И. Высокое искусство. Москва : Сов. писатель, $1988.352 \mathrm{c}$.

24.Шама И.Н. Перевод - искусство понимать... Запорожье : Просвіта, 2005. 240 с.

25.Шама И.Н. Функционирование символа в художественном тексте: сопоставительный и переводоведческий аспекты (на материале астральной символики «Вечеров на хуторе близ Диканьки» Н.В. Гоголя) : дис. ... канд. филол. наук : 10.02.19. Одесса, 1993. 278 с.

26.Шама И.Н., Андреева И.А. Символика границы в топографии завязки романа С. Кинга «The Tommyknockers» в оригинале и в переводе. Вісник ЗДУ. Філологічні науки. 2000. № 1. С. 219-222.

27. Awedyk S. On translating titles of literary works. Folia Scandinavica Posnaniensia. 1992. Vol. 1. P. 59-63. URL: https://pressto.amu.edu.pl/index.php/fsp/article/view/11120/10677.

28. Baugham M.G. Stephen King (Who Wrote That?). New York : Chelsea House, 2009. 136 p.

29.Behind the Name. URL: https://www.behindthename.com/ name/james

30. Biedermann H. Dictionary of Symbolism. Translated by J. Hubert. New York, Oxford: FactsOnFile, 1992. 465 p. 
31. Bloom H. Introduction. Stephen King (Bloom's Modern Critical Views) / Ed. by H. Bloom. New York: An imprint of Infobase Publishing, 2007. Pp. 1-3.

32. Bobadilla-Peréz M. Relevance and Complexities of Translating Titles of Literary and Filmic Works. Huarte de San Juan. Filologia y Didactica de la Lengua. 2007. N. 9. Pp. 117-124.

33. Bruce-Mitford M. Signs \& Symbols: An Illustrated Guide to Their Origins and Meanings. London, New York, Munich, Melbourne, Delhi: Dorling Kindersley Limited, 2008. 352 p.

34. Buday M. Demystification of Stephen King's Fiction in the Context of Postmodernism. Prešov: Vydavatel'stvo Prešovskej univerzity, 2015. 115 p. URL: https://www.researchgate.net/ publication/292149764

35. Cirlot J.E. A Dictionary of Symbols. 2nd edition. Translated from Spanish by J. Sage. London : Routledge, 1971. 451 p.

36. Collins Online English Dictionary. URL: https://www.collinsdictionary.com/dictionary/english

37. Cooper J.C. An Illustrated Encyclopaedia of Traditional Symbols. London : Thames \& Hudson, 1987. 208 p.

38. Delabastita D. Literary translation. Handbook of translation studies / Ed. by Y. Gambier \& L. van Doorslaer. Vol. 2. Amsterdam / Philadelphia : John Benjamins Publishing Company, 2011. P. 69-78.

39. Delabastita D. Literary studies and translation studies. Handbook of translation studies / Ed. by Y. Gambier \& L. van Doorslaer. Vol. 1. Amsterdam / Philadelphia: John Benjamins Publishing Company, 2010. P. 196-208.

40. Doyle M.S. Contemporary Spanish and Spanish American Fiction in English: Tropes of Fidelity in the Creation of Translation Titles. Translation Review. 1989. Vol. 30-31. P. 41-46. URL: https://doi.org/10.1080/07374836.1989.10523464.

41.Farghal M., Bazzi H. Translation of English fiction titles into Arabic. Translation and Interpreting. 2017. Vol. 9. № 2. P. 114-137.

42. Genette G., Crampé B. Structure and Functions of the Title in Literature. Critical Inquiry. 1988. Vol. 14. № 4. P. 692-720.

43. Greene A. Stephen King: The Rolling Stone Interview. The horror master looks back on his four-decade career. Rolling Stone. October 31, 2014. URL: https://www.rollingstone.com/culture/culturefeatures/stephen-king-the-rolling-stone-interview-191529/.

44. Hardacre H. Ancestors: ancestor worship. Encyclopedia of Religion / Ed. by L. Jones. Detroit, MI: Thomson Gale, 2005. Vol. 1. P. 320-325. 
45. Hemingway E. A Moveable Feast. London: Jonathan Cape, 1964. $199 \mathrm{p}$.

46. Iliescu-Gheorghiu C. What's in a title? A cognitive approach to the role played by translated text labels and (un)adapted semiotic elements. Revista Alicantina de Estudios Ingleses. 2001. № 14. P. 93-109. DOI : https://doi.org/10.14198/raei.2001.14.06.

47. King S. The Tommyknockers. N.Y. : A Signet Book, 1988. 747 p.

48.Landers C.E. Literary Translation: A Practical Guide. Clevedon, Buffalo, Toronto, Sydney : Multilingual Matters, 2001. 214 p.

49.Lemarié J., Lorch Jr.R.F., Péry-Woodley M.-P. Understanding How Headings Influence Text Processing. Discours. Revue de linguistique, psycholinguistique et informatique. A journal of linguistics, psycholinguistics and computational linguistics. 2012. № 10. URL: $\quad$ http://journals.openedition.org/discours/8600. DOI: https://doi.org/10.4000/discours.8600.

50.Levinson D. Religion: a cross-cultural encyclopedia. Santa Barbara, California; Denver, Colorado; Oxford, England : ABC-CLIO, 2011. $288 \mathrm{p}$.

51.Levý J. The Art of Translation / Translated by P.J. Corness. Ed. by Z. Jettmarová. Amsterdam. Philadelphia : John Benjamins Publishing Company, 2011.322 p.

52. Lodge D. The Art of Fiction. London: Vintage Books, 2011. 240 p.

53. Lotman Yu.M. The Semiotics of Culture and the Concept of a Text. Journal of Russian and East European Psychology. 1988. Vol. 26. Issue 3. P. $52-58$.

54. Lotman Yu.M. The symbol as plot-gene. Lotman Yu. M. Universe of the mind: A Semiotic Theory of Culture. Translated by A. Shukman. Bloomington and Indianapolis : Indiana University Press, 1990. P. 82-101.

55. Magistrale T. Hollywood's Stephen King. Palgrave Macmillan, 2003. 235 p.

56. Martashvili N.E. Nature of correlation of the title and literary text (on the basis of French literature). European science review. 2018. № 3-4. P. 301-303. URL: https://cyberleninka.ru/article/n/nature-ofcorrelation-of-the-title-and-literary-text-on-the-basis-of-french-literature.

57. Monaghan P. The encyclopedia of Celtic mythology and folklore. New York : Fact On File Inc., 2004. 512 p.

58. Nord Ch. Paving the way to the text: forms and functions of book titles in translation. Russian Journal of Linguistics. 2019. Vol. 23. № 2. P. 328-343. URL: https://cyberleninka.ru/article/n/paving-the-way-tothe-text-forms-and-functions-of-book-titles-in-translation

59. Nord Ch. Text Analysis in Translation Theory, Methodology, and Didactic Application of a Model for Translation-Oriented Text Analysis. 
Translated from the German by Ch. Nord \& P. Sparrow. Amsterdam, New York : Rodopi, 2005. 274 p.

60. Nsiah J., Marfo Ch. What's In a Title? A Reading of Amma Darko's The Housemaid. Matatu. Journal for African Culture and Society. 2011. Vol. 39. № 1. P. 363-375.

61.Perry M.A., McAleer P. Introduction: A More Subtle Macabre. Stephen King's Modern Macabre. Essays on the Later Works / ed. by M.A. Perry, P. McAleer. Jefferson, North Carolina: McFarland \& Company, 2014. P. 1-8.

62. Sapiro G. Translation and Symbolic Capital in the Era of Globalization: French Literature in the United States. Cultural Sociology. 2015. Vol. 9. Issue 3. P. 320-346.

63. Schaper B. The Importance of The Literary Title and Its Implications for Translation Theory. Focus on German Studies. 2013. Vol. 20. Cincinatti : McMicken College of Arts \& Sciences. P. 101-112.

64. Stolze R. Hermeneutics and translation. Handbook of translation studies / Ed. by Y. Gambier \& L. van Doorslaer. Vol. 1. Amsterdam / Philadelphia : John Benjamins Publishing Company, 2010. P. 141-146.

65. Strengell H. Dissecting Stephen King: from the Gothic to Literary Naturalism. The University of Wisconsin Press, Popular Press, 2005. 308 p.

66. Taha I. Semiotics of Literary Titling: Three Categories of Reference. Applied Semiotics / Sémiotique Appliquée (AS/SA). 2009. Vol. 9. № 22. P. 43-62.

67. Viezzi M. Titles and translation. Haasteena, Perspektivet som utmaning, Point of View as Challenge, Perpektivitat als Herausforderung. VAKKI-symposium XXXIII 7.-8.2.2013. Ed. by M. Eronen, M. Rodi-Risberg. Vaasa: VAKKI Publications, 2013. Vol. 2. P. 374-384. URL: http://www.vakki.net/publications/ 2013/VAKKI2013_Viezzi.pdf.

68. Wood R. Stephen King : a literary companion. Jefferson, North Carolina, London : McFarland \& Company, Inc., 2011. 214 p.

Information about the author: Shama Iryna Mykolaivna, Candidate of Philological Sciences, Associate Professor, Associate Professor at the English Philology Department Zaporizhzhia National University 66, Zhukovsky str., Zaporizhzhia, 69600, Ukraine 